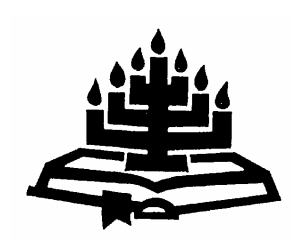

\title{
Acts 17:16-34 as paradigm in responding to postmodernity
}

\author{
G.A. Lotter \& G.G. Thompson \\ Faculty of Theology \\ Potchefstroom Campus \\ POTCHEFSTROOM \\ E-mail: kwsgal@puk.ac.za \\ ggthompson@rogers.com
}

\begin{abstract}
Acts 17:16-34 as paradigm in responding to postmodernity

This article shows, in the description of Acts 17:16-34, important guidelines that may be found from Biblical material and how to understand and respond to postmodernity today. The main argument of this article is discussed under the following headings: Paul and Hellenistic pluralism; idols and gods: pluralism par excellence; Paul in Athens: prolegomena (Acts 17: 16-21) and Paul's address to the Areopagus (Acts 17:22-34). Similarities between the situation in Athens will subsequently be discussed, followed by guidelines from Acts 17 to address postmodernity: the primacy of Biblical revelation, the utilisation of apologetics and flexibility through contextualisation. Finally, it will be shown how Paul did not assume a combative posture, but how with admirable delicacy, he challenged and corrected the major positions of the Stoics and the Epicureans, whilst being sensitive towards the Athenians. He portrayed how the message of the gospel can be conveyed by speaking relevantly and pointedly in the same manner to postmodern society.
\end{abstract}

\section{Opsomming}

Handelinge 17:16-34 as paradigma in reaksie op postmodernisme

Hierdie artikel wys in die bespreking van Handelinge 17:16-34 op die belangrike riglyne wat na vore kom uit die Bybelse materiaal en hoe om die postmodernisme te begryp en daarop te reageer. Die hoofgedagte van hierdie artikel word onder die volgende opskrifte bespreek: Paulus en die Hellenistiese pluralisme; afgode: pluralisme by uitstek; Paulus in Atene: prolegomena (Handelinge 17:16-21) en Paulus se rede op die 
Areopagus (Hand. 17:22-34). Ooreenstemming tussen die situasie in Atene en die huidige postmodernisme word vervolgens behandel, gevolg deur riglyne uit Handelinge 17 hoe om die postmodernisme te hanteer: die primêre belang van Bybelse openbaring en die gebruik van apologetiek en aanpasbaarheid deur kontekstualisering. Ten slotte word aangetoon dat Paulus nie met 'n gesindheid van veglustigheid opgetree het nie, maar met takt en oorleg het hy die standpunte van die Stoisyne en die Epikureërs uitgedaag en gekorrigeer, terwyl hy deurgaans sensitief teenoor die Ateners gebly het. Hy het gedemonstreer hoe die boodskap van die evangelie ook in die postmoderne samelewing oorgedra kan word op 'n relevante en gerigte wyse.

\section{Introduction}

In the New Testament, and particularly Acts 17:16-34, a vital clue may be given on understanding and responding to postmodernity today. The possibility thereof will be researched in this article. The main argument of this article is that Paul's encounter with Athenian society, riddled with deities and ideologies, could be used with some adaptations to provide guidelines for proclaiming the gospel in postmodern times. Before considering the text itself, it is necessary to conduct a brief tour of the religious landscape into which the Apostle Paul ventured. Some pointers on postmodernity will be mentioned and similarities between the situation in Athens and our current situation will consequently be discussed, followed by guidelines from Acts 17 to address postmodernity.

\section{Paul and Hellenistic pluralism}

The period from Alexander to Augustus, 330-30 B.C., is known as the Hellenistic age (cf. Ferguson 1987:1). The term Hellenism refers to "the expansion of the Greek language and culture and, most of all, the establishment of the Greek's political domination over other nations of the east" (Koester, 1982:39). The process by which Greek culture rose to the position of dominance is largely attributed to the conquests of Alexander the Great (356-323). Before Alexander, Greece expanded through the formation of new colonies. However, the Persians held the title of the leading world power (Thompson, 2000:67). When Alexander defeated the Persian king, Darius III, at Issus in 333 B.C., the balance of power in the Mediterranean world swung to Greece. However, Alexander's sudden death plunged the Hellenistic empire into civil war, with Alexander's successors, the Diadochi-battling, for overall control. Nevertheless, Hellenisation advanced under the Ptolemaic and Seleucid kings. The Greek 
language became the lingua franca of the territory from Rome eastward (cf. Koester, 1982:42). The political power of the Greek Empire gradually declined and by the first century it relinquished power to the Roman Empire. Nevertheless, Greek influence remained strong because of the fusion of Greek and Roman cultures.

\subsection{The imperial cult}

The Graeco-Roman or the Hellenistic world of the apostle Paul was a time of philosophical diversity and more importantly, religious syncretism (cf. Koester, 1982:164). The first and most evident indication of the religious pluralism of Paul's day was the presence of the imperial cult. Winter (1994:93) asserts, "from the beginning there existed two imperial cults in the provinces - Rome and the divine Julius". The idea of an imperial cult had its origin in both Greek and Roman fascination with their rulers. Eventually, these rulers were accepted as the epiphany of gods and thus shrines were erected in their honour (cf. Koester, 1982:367). The imperial cult was widespread in the Mediterranean world many years before Christianity; it flourished in provinces from Galatia to Achaia (cf. Winter, 1994:94).

\subsection{The pantheon}

Perhaps the most dominant form of Hellenistic pluralism Paul encountered came in the form of the Greek pantheon. Twelve gods generally make up the Greek pantheon (cf. Ferguson, 1987:115). The Roman gods and goddesses were in fact Greek, except for the change of names. Gill (1994b:81) identifies the gods of the first century as Greek in origin: "The cults met by Paul and the early Church in Acts tended to be the long-standing Greek or local cults." The worship of these gods was not uniform during this period and it is likely that each city-state had its own patron god or goddess. Vos (1988:109) explains: "Religion was bound up with the life of the citystates." The worship of the various deities was neither casual nor disinterested. To the contrary, the first century paganism that confronted "early Christianity in the eastern Mediterranean was robust and pervasive, not impotent and quarantined" (Sloan, 1994:515).

In his travels, the apostle Paul found many examples of established cults in honour of various members of the pantheon. Zeus was popular in many cities including Laodicea, Lystra and Pergamum (cf. Sloan, 1994:517, 521, 522). The book of Acts confirms that Zeus 
was a patron deity in Lystra. Paul arrived in Lystra where he healed a lame man (Acts 14:10). The people were convinced that Paul and Barnabas were gods who appeared as men (vs. 11). They identified Barnabas as Zeus and Paul as Hermes (vs.12). The fact that there was a priest of Zeus in Lystra signifies the presence of the cult of Zeus in the city (vs. 13).

Another member of the pantheon with wide support during Paul's time was the cult of Artemis (Roman Diana). She was the manybreasted goddess of fertility, who had supernatural powers to heal (cf. Trebilco, 1994: 317, 319). Apart from the archaeological support, the words of Demetrius, the silversmith who opposed Paul's evangelisation of Ephesus, give an idea of her popularity in Asia:

Not only is there danger that this trade of ours fall into disrepute, but also the temple of the great goddess Artemis to be regarded as worthless and that she whom all Asia and the world worship will even be dethroned from her magnificence (Acts 19:27).

Dionysus or Bacchus, the god of wine, was perhaps the most popular in the Hellenistic world (cf. Sloan, 1994:518). Rogers, (1979:254) describes the essential element of this cult:

The festivals celebrated in honour of Dionysus varied from place to place, but it seems that one common feature was the emphasis on fertility and sex. The emphasis on the phallus (the male sex organ) in the so-called 'Phallus Procession' along with such things as 'the Phallus Song,' certainly indicate the lewd debauchery connected with this worship. The significance was evidently to please Bacchus so that he would grant fertility.

Although there is no specific reference from the book of Acts that Paul confronted this cult in his missionary journeys, it is not credible that he was unaware of Dionysus worship. In Athens, for instance, there was a five-day celebration in his honour (Sloan, 1994:518). If Rogers (1979:251) is right, Paul would have met this cult several times:

The worship of Dionysus spread throughout Asia Minor, Macedonia, Greece, Italy, Egypt, Palestine, and even India. By the time of the Apostle Paul, the cult of Dionysus or Bacchus was well established in most of the major cities in which Paul preached. 


\subsection{Mystery and magic cults}

In the Hellenistic world of Paul, there were several prominent mystery cults: Eleusis, Isis, Cybele, Mithras and Men (cf. Hansen, 1994:393; Gill, 1994b:89). The rising popularity of mystery religions during the Greco-Roman period rests upon several factors. However, the two most distinguishable factors are the growing disaffection in several quarters with the traditional gods and goddesses and the nature of mystery religions. First, the vacuum created by the departure from traditional gods and goddesses provided an excellent opportunity for mystery religions to flourish. Second, the nature of mystery religions proved fascinating to many on the hunt for a new faith (cf. Metzger, 1983:66). These mystery religions, largely imported from the east, offered novel practices in initiation rites, ritual sacrifices, festivities and meditation (cf. Sloan, 1994:520). Coupled with their novelty was the accent on secrecy. Both these elements proved attractive to many (cf. Metzger, 1983:66). To a lesser extent, mystery religions appealed to some because they attempted an explanation of the cosmology through the death and resurrection of their divinities (cf. Vos, 1988:114).

Magic was also a part of the Graeco-Roman world of Paul. The early church in its evangelism among the gentiles encountered the practice of magic. The apostle Peter rebuked the sorcerer named Simon living in Samaria. He amased people with magic and earned the name, Great Power of God (Acts 8:10). Paul met a magician and false prophet at Paphos (Acts 13:6). At Ephesus the practise of magic was popular. There they had books on the subject of magic, which when burnt were estimated at 50000 pieces of silver (Acts 19:19). The emergence of magic in the Mediterranean world was the result of Greece's contact with the East and its religions (Koester, 1982:376).

\section{Idols and gods: pluralism par excellence}

The quick glance at Hellenistic pluralism shows that Paul's world was crowded with a multiplicity of idols. The pervasive influence of idols often reveals itself through explicit references to idolatry in the New Testament. In the book of Acts the Jerusalem Council instructed gentile converts to abstain from things contaminated by idols (Acts 15:20). In Corinth, Christians were troubled over meat sacrificed to idols (1 Cor. 8:7-13). Christians were described in their former lives as idolaters (Gal. 4.8; 1 Thess. 1:9). The New Testament further discloses that idols still pose a threat after 
conversion, hence John's command: "Little children guard yourselves from idols" (1 John 5:21).

The references above provide additional substantiation that the first century world was overcrowded with idols. The world in which Paul proclaimed the gospel was hostile territory. Sloan (1994:523) outlines succinctly a likely reason for this hostility:

The masses of pagans were polytheists. Business, government, home life, theatre, athletics, all were under the care of various gods .... For pagans it was not enough to worship a God, as Jews and Christians did. The mass of pagans viewed monotheists as little better than atheists.

Although Paul's world differs in many ways from the world we know today, our postmodern world is comparable in its religious and philosophical pluralism. This point will receive elaborate treatment. Acts 17:16-34 records Paul's outreach to a city congested with idols and ideologies. This is relevant for us, because it supplies us with a number of useful insights to aid our address in a postmodern society infested with its own gods ranging from Mammon to Aphrodite.

\section{Paul in Athens: prolegomena (Acts 17:16-21)}

The next section will attempt a brief exegesis of the passage before proposing some recommendations from the text.

The introductory clause from Acts 17:16, "while Paul was waiting for them at Athens", makes the transition from the preceding verses, and at the same time it provides the setting for what follows. Paul arrived in Athens by sea from Macedonia. He was fleeing Jewish persecutors who had pursued him from Thessalonica to Berea (Acts 17:10-15 13). He was in Athens awaiting Silas and Timothy to rejoin him (cf. Acts 17:14-15).

Athens was named in honour of the goddess Athena. Throughout the Graeco-Roman world, Athens was known as the centre of art and philosophy (Kee, 1997:209). By 479 B.C. Athens had emerged as the strongest state in Greece after two successful wars against the Persians (cf. Blevins, 1990:444). Athens was the cradle of democracy and during its golden age (478-431 B.C.) great strides were made in art, sculpture, and philosophy (cf. Bruce, 1990:375; Blevins, 1990:444). Athens was also the headquarters of the four prominent philosophical schools: the Academy, the Lyceum, the Garden and the Porch (cf. Blevins, 1990:444). Defeat at the hands of the Romans in 146 B.C. however, signalled the eclipse of Athens 
commercially and politically, especially by Corinth (cf. Johnson, 1997:194). Notwithstanding, Athens retained prestige as the great university city.

Paul was not the typical tourist, marvelling at the artistic and architectural feats of the city. The verb parwxuneto, the third person, singular, imperfect, passive, has the inceptive sense; it means he became agitated. The English word paroxysm used for an epileptic fit is coined from this Greek word (Stott, 1990:278). In the LXX, paroxunw is the term employed to express God's extreme anger against the idolatry of the covenant people (cf. Deut. 9:7, 18, 22; Ps.106:29; Isa. 65:2-3; Hos. 8:5). This word describes Paul's monotheistic zeal and his "fundamental horror of idolatry" (Bruce, 1990:376).

The reason Paul was provoked in his spirit lies in the condition of the city. Luke uses the adjective, thick with idols, to illustrate the extreme polytheism of the city. Paul's first view of Athens perhaps included the 500 feet hill, which towered over the city upon which the temple of Athena was erected (cf. Kee, 1997:209). Gill (1994a:444) visualises the visible idolatry of Athens, which so provoked Paul, as follows:

He would have been able to view at least two of the structures connected to the worship of the emperor: in front of him in the Agora, the temple of Ares, and beyond that on the skyline, the temple of Roma and Augustus. Moreover, to his right, the Stoa of Zeus Eleutherios may have housed the imperial cult in the Agora .... Many of the thirteen small altars dedicated to Augustus, with implications for divinity, were found in the agora area. A statue base of Livia (as Julia Augusta) was found to the east of the Metroon ... and this linked here with the deity Artemis Boulaia. Yet, there would be other centres of cults, in and around the Agora. Perhaps he would have included the Tyrannicides, Harmodios, and Aristogeiton, which stood next to the temple of Ares. Most obvious ... were the temples of historic Athens: to the right, on the Stoa Agoraios, the temple of Hephaistos, and in front of the acropolis with, among other things, the Erectheion and the Parthenon.

The construction men oun (v. 17), is the transitional participle so; it marks a new division in the narrative by describing Paul's response to Athens' idolatry. The compound verb dielegeto (he was reasoning), is the imperfect middle of dialegomai. The 10 occurrences of the word in Acts describe Paul's address in the synagogues (Acts $17: 2,17 ; 18: 4,19 ; 19: 8$ ), the school of Tyrannus 
(Acts 19:9), Christian gatherings (Acts 20:7, 9), the temple (Acts 24:12) and before Felix (Acts 24:12). The passages above show that dialegomai does not generally convey the idea of debate or discuss. Marshall (1992:31) summarises the lexical evidence:

There is, therefore, sufficient evidence to show that the preaching of the early Christians could lead to debate and discussion with the hearers. But it is clear that the emphasis falls upon the preaching of the gospel.

In the light of the above discussion, it seems unlikely that dialegomai means that Paul debated as an equal partner with the Jews, proselytes and philosophers of Athens. Rather, dialegomai is descriptive of Paul's method to use logic and rhetoric to persuade (cf. Witherington, 1998:514).

Paul's customary approach on his missionary journeys was to visit firstly the synagogue in the cities and to appeal to Jews and Godfearing gentiles (cf. Acts 10:2; 17:2-4). Paul followed the same routine in Athens. The text, however, shows that Paul's evangelism was not limited to the synagogue. Like Socrates before him, he went to the Agora, the cultural heart of the city located to the west of the Acropolis. This was both the market and a place for philosophical discussions (cf. Stott, 1990:280). This proves that Paul was willing to speak to anyone who would listen to him.

In verse 18, the reader is introduced to the two rival schools of philosophy in Athens: the Epicureans and the Stoics. The Epicureans followed the teachings of Epicurus (341-270 B.C.). They were materialistic in outlook and the main teaching was that the goal of life is happiness (cf. Kee, 1997:212). They believed that although the gods probably existed, they were indifferent to human affairs. The world was not created, man had neither purpose, nor a future after death. Consequently, for Epicureans, the pursuit of life was pleasure and peace (Johnson, 1997:195).

The Stoics were disciples of Zeno (340-265 B.C.). They took their name from the Stoa where they frequently met. The Stoics taught the importance of living harmoniously with nature (cf. Fitzmyer, 1998:605). They emphasised man's rational abilities over the emotions. They were pantheistic; God was the world soul. Moreover, the Stoics taught that one "should accept with courage and indifference the vicissitudes and painful experiences of life" (Kee, 1997:213). "Great moral earnestness and a high sense of duty" marked Stoicism (Bruce, 1990:377). The Epicureans were the deists of the day, while the Stoics were the pantheists. These philosophies 
were opposed to Christian doctrine of God, sin, redemption and eternal life.

Verse 18 tells us that some from the Epicureans and Stoics were arguing with Paul. The word sunballon, (cf. also vs. 16, 17) indicates that Paul was constantly facing opposition. The opposition of the Epicureans and the Stoics emerges in the conditional sentence: "What does the seed-picker wish to say?" The protasis "if it were possible" is implied (Wallace, 1996:484). The word spermologo is literally seed-picker. Firstly it refers to birds picking up grains, secondly to men picking up miscellaneous items and then to worthless persons (cf. Louw \& Nida, 1988 [33.381]). In this context, seed-picker is derogatory. These philosophers charged Paul with plagiarising and peddling second-hand other people's ideas and opinions without understanding them (Bruce, 1990:377).

The next group misunderstood Paul's preaching, interpreting it as drumming up support for two new gods. Luke introduces the parenthetical clause "because he was preaching Jesus and the resurrection" to explain why they thought Paul was introducing foreign gods. This second group probably thought Jesus was a god and Anastasis a female deity coequal with Jesus (Garland, 1992:188; Metzger, 1994:404; Winter, 1996:85). The charge that Paul was an advocate of foreign gods was not derogatory, but dangerous, because it was the same charge which led to the death of Socrates (cf. Witherington, 1998:515).

According to verse 19 the scene is set for Paul's address. To take hold of, to grasp, could either mean to lead a person (Acts 9:27; 23:19), or to arrest someone (Acts 16:19; 18:17; 21:30, 33). The word by itself is inconclusive; the choice between lead or arrest depends on how one views the sharpness of the conflict between Paul and the philosophers.

Areopagus is literally the Hill of Ares, situated "to the north west of the acropolis in Athens" (Fitzmyer, 1998:605). Ares was the Greek god of war, equivalent to Mars, the Roman god of war. Either Paul was lead to the hill itself or before the ruling body of Athens which took its name from the Areopagus. The latter view enjoys the greater support (cf. Dunn, 1996:234; Gill, 1994a: 447; Hemer, 1990:117). Some commentators understand this to mean that Paul was judicially indicted (cf. Soards, 1994:96; Kistermaker, 1990:628). However, there is no hint from the text of any legal proceedings. It may indicate that this was an informal meeting of the court (Marshall, 1980:285). 
The council presents Paul with their request: "May we know what this new teaching is which you are proclaiming?" The verb to know occurs again in verse 20; it stresses the role of knowledge among Paul's interlocutors. The adjective new, is emphatic and it could signal sarcasm on the part of Paul's audience (cf. Williams, 1985:304). Verse 21 is parenthetical as Luke explains the reason Paul appeared before the Areopagus. Luke describes the Athenians and their visitors as habitually discussing some new thing. This view of the Athenians is not only Luke's assessment. As early as the fourth century B.C., Demosthenes alluded to their interest in hearing new things (cf. Fitzmyer, 1998:606).

\section{Paul's address to the Areopagus (Acts 17:22-34)}

Verse 22 begins a new section in which the apostle attempts to extricate himself from the accusation that he was promoting foreign gods. He also "seeks a point of contact for his proclamation of the unknown god" (Hansen, 1998:315). Paul was perhaps standing in the midst of the council - the prepositional phrase makes better sense if it refers to the council, rather than to the hill (cf. Bruce, 1990:375; Kistermaker, 1990:630). However, the physical location is not crucial; it is the address which requires scrutiny. Paul's opening line, "Men of Athens" is reminiscent of the formula orators used to address the Areopagus (cf. Kistermaker, 1990:630).

Paul's observation that they were very religious is used with an elative sense (cf. Wallace, 1996:300). The word may be used positively or negatively. It may be interpreted as "very religious or superstitious" (Louw \& Nida, 53.3). However, it is doubtful that the word carries the negative connotation, superstitious, especially since Paul seeks to make contact with the audience (cf. Acts. 25:19). Paul does not commend the Athenians for idolatry; this will become clear as the speech develops.

The reason Paul assesses that they are very religious, is due to the objects of worship (cf. 2 Thess. 2:4) he observed as he was passing through Athens. Such objects perhaps included altars and images. He points out the altar with the inscription, To an Unknown God. Paul considers it a frank admission of ignorance by the Athenians. Paul denies that he proclaims new gods with the expression, "that which you worship in ignorance". Since by their altar they admit their ignorance, Paul announces that his intention is to educate them concerning this unknown God. The neuter construction, that, instead of the masculine, whom, indicates that they worship an impersonal god. Paul expresses his intention forcefully, this I proclaim to you. 
The personal pronoun ego, is emphatic; it stresses the apostle's resolve to proclaim the unknown God as the only God (Dunn, 1996:235). Although his audience was mainly philosophers, Paul did not engage them in "a reasoned philosophical argument" (Fitzmyer, 1998:607); instead, he proclaimed the kerygma.

With the statement in verse 24 that the unknown God is "the one Creator God of all the universe, and its contents" Paul begins a series of statements about God and his character (cf. Soards, 1994:97). He undercuts both the Epicureans and Stoics conceptions of the universe. Stott, (1990:285) states:

This view of the world is very different from either the Epicurean emphasis on a chance combination of atoms, or the virtual pantheism of the Stoics.

Paul is emphatic, this same God is Lord of both heaven and earth (cf. Ex. 20:11; Isa. 42:5; Acts 14:15). Paul pictures God as the personal kurios who "governs and cares for all that He has made including this Athenian audience" (Kistermaker, 1990:633). The argument flows logically: if God is Creator and Lord of the cosmos, then it is unthinkable that his location is confined to man-made shrines (cf. 1 Kings 8:27; Isa. 57:15; Acts 7:48). Paul distinguishes the true God from the various Greek gods with their temples in Athens (cf. Fitzmyer, 1998:608). Since God does not live in manmade temples, by implication, humans cannot domesticate him (cf. Soards, 1994:97).

In verse 25 the conjunction nor, continues the distinction between God and his creation. Paul argues the independence of God through the clause, "neither is He served by human hands, as though $\mathrm{He}$ needed anything". The emphasis upon human hands is a forceful statement that God lacks nothing that man must supply. The reverse is true: "He Himself gives to all life and breath and all things." Paul posits God as the source and sustainer of life and breath; these are synonymous expressions (cf. Isa. 42:5). Paul finds common ground with both Epicureans and Stoics here by noting that God needs nothing, and that he gives life to all things (cf. Witherington, 1998:525).

Paul progresses to God's creation of man (v. 26). The clause, "from one He made every nation of men" is Paul's way of saying all men share a common origin. The phrase of the one, stops short of naming the person, but the reference is to Adam. Bruce (1990:382) explains Paul's remark about the solidarity of the human race: "The Greeks in general considered themselves superior to non-Greeks, 
whom they called barbarians. Against such claims to racial superiority Paul asserts the unity of all mankind, a unity derived 'from Adam'."

The times God had providentially determined beforehand could be either seasons or the eras that belong to particular nations (v. 26). Since Paul speaks about nations, the latter interpretation seems preferable (cf. Kistermaker, 1990:635). He also determined the places where each nation would dwell.

Soards (1994:97) sees verse 26 as indicative of God's sovereign dealings with humanity. However, this verse teaches important lessons that both the Stoics and Epicureans needed to learn. Fitzmyer (1998:609) captures best Paul's thinking in this passage:

Paul stresses the unity of all humanity and its nearness to this creator God. He does this by insisting that God has put all human beings on this earth and is thus countering the idea that the universe came into being by chance, emphasising rather the divine design and intention that lies behind all human existence.

The infinitive clause in verse 27 articulates God's purpose for creating man; he should seek God. Both verbs are in the optative mood. There is no certainty that man on his own could find God; the optative mood refers to a remote possibility (cf. Wallace, 1996:484). The verb to grope, indicates a searching in the darkness (cf. Bruce, 1990:383; Louw \& Nida, 27.40). The concessive kai ge, "and yet God is not far from us" makes it clear that God is near. This was a current thought in Stoic philosophy (Marshall, 1980:288).

For confirmation of God's imminence, Paul quotes from a Greek poet "in Him we live, move, and exist". Some attribute the quotation to the poet Epimenides, a poet who lived in Crete in the sixth century B.C. (cf. Hemer, 1990:118). God is the source of life and provides power for activity. Paul stresses mankind's dependence upon God for physical, spiritual and intellectual life (cf. Hansen, 1998:316; Witherington, 1998:529). The second quotation is from the third century B.C. poet Aratus, who was well known to the Stoics (cf. Kee, 1997:216). Through this quotation, Paul establishes humanity's relationship to God; we are his children because of special creation.

In verse 29, the particle therefore, indicates a shift in the address. Paul is about to apply his message to the audience (cf. Kistermaker, 1994:634). The apostle grounds his attack on Athenian idolatry, 
because they were God's offspring. Since God is man's creator, therefore to imagine the divine nature, like images of silver, gold, stone or any man-made object is obviously wrong. Paul attacks Athenian baseless idolatry in this verse. Inanimate objects serve only to impose limits and to demote the Creator to some image of our creation (cf. Dunn, 1996: 236; Stott, 1990:287).

Paul says God overlooked their ignorance in the past (v. 30, cf. also v. 23). It does not mean that in the past God regarded their ignorant idolatrous practices with indifference (cf. Bruce, 1990:385). God treated them with patience, but it was not his intention that people should persist in idolatry (cf. Barrett, 1998: 851). Nun, now, signals the transition from the past to the present. God now summons all people everywhere to repent. This command is for a radical change of mind and behaviour, particularly in the area of idolatry.

The call for repentance is all the more important because of the certain judgement. Paul underlines the certainty of judgement by establishing two truths. Firstly, God has determined a day of judgement. Paul's day of judgement corresponds to the Old and New Testament's theme of the Day of the Lord (cf. Amos 5:18-20; Mal. 4:5; 1 Cor. 5:5; 1 Thess. 5:2; 2 Pet. 3:10). Secondly, He has appointed the Judge. The personal agent of judgement is described as "a man God raised from the dead". The Judge, therefore, is the resurrected Jesus Christ referred to in verse 18. Furthermore, Paul includes the concept righteousness to convey the fairness of the judgement. The extent of Christ's judgement is the whole world. By implication, even the Athenians will face the resurrected Christ.

Verse 31 ends Paul's speech in Athens. These verses relate the mixed response Paul's message received. Some mocked the idea of the resurrection. The people of Athens believed that there was no resurrection (cf. Witherington, 1998:532). Especially for the Epicureans who denied the resurrection, this would be difficult to accept. Others showed some interest when they told Paul, "We shall hear you again concerning this" (v. 32). It is unclear whether this is a polite dismissal or genuine expression of interest in further discussions. The fact that Paul did not take up their offer, but left Athens soon afterwards for Corinth (cf. Acts 18:1), is perhaps proof that their comment was a polite but firm rejection of the apostle's message (cf. Fitzmyer, 1998:612).

Dunn (1996:238) sums up Paul's time in Athens as largely unproductive: "All told, the experience in meeting Greek philosophy in Athens head on does not appear to have had a lasting success 
and probably left its most lasting influence in Paul's formulations in Rom.1 and Cor.1."

Luke informs us that Paul's encounter with the Areopagus was not a complete failure. Some in the audience accepted the message. Luke singles out Dionysius, the Areopagite, and a woman called Damaris as two from the few who believed Paul (v. 34). However, it seems that most of those who heard the apostle remained unconvinced by his message.

\section{Similarities between the situation in Athens and postmodernism}

Postmodernism opposes or questions the ideals, ideas, attitudes and values of modernism (cf. McGrath, 1996:185) and refers to "a movement as well as mood" (Guinness, 2000:52). However, the most popular definition comes from Lyotard (1984:xxiv). He defines postmodernism as "incredulity towards metanarratives". The first century Athens into which Paul stepped has some similarities with our times (see 2 above). Proctor (1992:69) notices this: "It is not so far from Athens in the middle of the first century to the places where you and I sit at the end of the twentieth." Unquestionably, the most conspicuous similarity between Athens and our postmodern times is the shared pluralism.

\subsection{Pluralism}

Charles (1995:51) states that the intellectual atmosphere of first century Athens might be characterised as mildly promiscuous, both in religious and non-religious sense. Berger (1992:9) also concurs: "Modern societies ... share with the Hellenistic world the complicating factor of pluralism." Athens was a city known for both philosophical and religious pluralism. It was the home of several philosophical schools. In fact, the four great schools: the Academy, the Lyceum, the Garden and the Porch still had their headquarters in Athens (Blevins, 1990:444). The religious pluralism of Athens ranged from emperor worship to individual members of the Pantheon.

Equally, the postmodern agora or market place cherishes both philosophical and religious pluralism (Thompson, 2000:51). It is possible, for instance, in the postmodern climate to hold any worldview, even if its "epistemic justification" rests on a questionable foundation (cf. Wood, 1998:106). Therefore, like Athens, our religious landscape bears the mark of religious diversity. 


\subsection{Biblical illiteracy}

Despite the religious diversity of Athens, "the city had no discernible knowledge of the Old Testament revelation" (Charles, 1995:51). If this interpretation is correct, then knowledge of Jesus Christ was equally non-existent in Athens. The plethora of gods and the altar to the unknown god demonstrate not only biblical illiteracy, but also gross religiosity on the part of the Athenians.

The postmodern society likewise betrays signs of growing biblical illiteracy. Carson (1996:43) assesses that "an entire generation will be even theoretically ignorant of the most elementary structures of the Judeo-Christian heritage on which our civilisation has been nurtured".

Our postmodern society is characterised by biblical illiteracy and attendant superstitious beliefs. Proctor (1992:71), for example, points to the current fear of the number thirteen, consulting of horoscopes and the "belief in unknown elements in the universe" as further proof that the postmodern society, like its Athenian counterpart, is highly superstitious.

\section{Guidelines from Acts 17 to address postmodernism}

Acts 17:16-34 not only reveals similarities with postmodern society, it contains general guidelines which should inform our approach to postmodernists. Although these guidelines are far from exhaustive, they provide indispensable insights that will be discussed shortly.

\subsection{The primacy of Biblical revelation}

At the heart of Paul's address is Biblical revelation. The address is largely theocentric and monotheistic in nature. Paul describes God as the personal and transcendent One (vs. 24, 26, 29), Creator and Lord of mankind (vs. 24-26), accessible to his creatures (vs. 27-28), and Judge of mankind (vs. 31).

Understandably, any proclamation of the Christian God to postmodernists may prove jarring to their ear. Nevertheless, meaningful evangelism is impossible without first establishing God as Creator. Paul knows this and hence his clarification of the Christian God. Paul's sermon is instructive, because it establishes the necessity of returning to basic truths, such as the doctrine of God when evangelising (neo-)pagans. 
Another aspect of Paul's address is its Christocentric strain. Even before he appeared before the Areopagus, Paul was preaching Jesus and the resurrection day after day in the marketplace of Athens (vs. 18). Luke does not supply an exhaustive account of what Paul included in his discourses about Jesus. However, one may assume those rudimentary aspects, such as that his divinity, incarnation, atonement and resurrection, received special mention. What is certain, however, is that Paul's Areopagus address refers to Jesus' judicial role in the approaching assise (vs. 31).

Like the Athenians, postmodernists need to hear Paul's twin emphases, God revealed and Christ risen. Particularly, this latter emphasis of Paul on Christ and the resurrection should also figure prominently when we witness to postmodernists. The uniqueness of the Christian message is the good news of the resurrected Lord Jesus. Preaching or witnessing in the postmodern context must have as its focal point: Christ above the postmodern gods.

The anthropocentric stress in the Areopagus sermon is conspicuous. Paul asserts that man is a creature of God with an appointed time and place (vs. 26), and the onus of seeking after God (vs. 27). According to Paul, mankind stands guilty of idolatry (vs. 29), and needs urgently to repent (vs. 30), since God's righteous judgement is inevitable (vs. 31). Proclamation to postmodernists should insist on the relationship between the creature and the Creator, as well as the sinfulness of man.

Understandably, some may raise objections to the suggestion that Paul's starting point of Biblical revelation bears imitation, since postmodernists are vehemently opposed to such doctrines as God, Creation, the Fall, Christ, and the Judgement. While it is true that postmodernists consider these doctrines objectionable, because they constitute the Biblical metanarrative, still Paul proclaimed them, not because the Athenians wanted to hear them, but because they needed to hear them. Hancock (1994:12) is right: "Dialogue breaks down when Paul mentions the resurrection." Interestingly, the thought that this could occur did not deter him, and therefore ought not to deter us.

\subsection{The utilisation of apologetics}

From the brief exegesis attempted above, the apologetic thrust of Paul's sermon is already established. Although Paul names neither the Stoics nor the Epicureans, there is universal agreement that these two groups were foremost in Paul's mind as he preached. 
The Stoics identified God with the world. Paul refutes their pantheism by declaring a personal God who is transcendent and majestic (cf. Proctor, 1992:70). Against the Stoics' self-sufficiency, Paul portrays God as the truly independent One (vs. 25) and man as dependent upon Him for life and breath (vs. 28). In addition, Paul attacks the Stoics' morality by charging them with idolatry (vs. 29). Contrary to their apatheia (cf. Wood, 1998:46), Paul highlights the urgency of the coming judgement (vs. 31). It appears that the apologetic design of Paul was to humble the Stoics by exalting God.

The Epicureans, on the other hand, believed that even if there were a God, He was far removed from the creation. Proctor (1992:71) describes the thinking of this group:

The Epicureans said, 'I lead a quiet decent, respectable life. I don't bother anyone and nobody bothers me. I doubt if God has much to be concerned about in what I do - which is alright, because he doesn't trouble me either.'

The Epicureans, with this mentality, did not elude the sharp barb of Paul. God, far from being disinterested in his creation is personally involved. His involvement takes the form of sustaining the creation (vs. 28), forebearing with their former ignorance (vs. 30) and the determination to hold men accountable at the judgement (vs. 31).

The apostle Paul shows that he understood the worldviews of the inhabitants of Athens (cf. Thompson, 2000:68). Armed with this knowledge, he could formulate a pointed criticism of the Stoics and Epicureans' erroneous assumptions. Gospel proclamation today needs to show an understanding of the postmodern worldview; moreover, such proclamation must include some apologetics with the intention of demolishing the ideological strongholds of postmodernists.

\subsection{Flexibility through contextualisation}

Paul was faithful in the declaration of the gospel in Athens. Charles (1995:54) sees this faithfulness demonstrated in Paul's insistence on "creatio ex nihilo and bodily resurrection the core of the Christian kerygma". Yet, his methodology in Athens differs from other occasions, for instance, his preaching in the synagogue of Pisidian Antioch (cf. Acts 13:14-41). In Acts 13 Paul's audience is Jewish, schooled in the Old Testament; hence, his sermon contains references to Israel's election, God's provision of land, Israel's leaders, the Messiah's Davidic ancestry, and direct quotations from Scripture (cf. Johnson, 1997:158). Here in Acts 17 Paul displays 
sensitivity to his audience. He avoids direct references to Scripture; instead, he quotes two familiar Greek poets, Epimenides of Crete and Aratus of Cilicia.

Paul's careful approach to Athenian society reveals itself in simple ways such as his introductory statement: "Men of Athens, I observe that you are very religious in all respects." Carson (1996:498) accurately interprets this comment as courteous and sensitive. Although Paul does not approve of their religiosity, he nevertheless treats the Athenians with dignity, since unnecessary offence would prove counterproductive to his evangelistic purpose.

Sensitivity for context is most obvious from Paul's reference to the altar of the unknown God. Johnson (1997:197) observes that Paul's point of contact with the residents of Lystra (Acts 14:17) were "the phenomena of nature and agriculture as God's testimony to His dominion". However, in Athens the concrete and readily identifiable altar became Paul's text in clarifying that their unknown God is the Creator who delineates the temporal and geographical limitations of the human family (cf. Johnson, 1997:197).

The necessity of adapting one's message in order to be contextually relevant is an established principle among missiologists; in Acts 17:22-31 Paul gives it Biblical legitimacy. Naturally, to evangelise postmodernists we must give due attention to the issue of contextualisation.

\section{Conclusion}

Acts $17: 16-34$ is crucial to the development of a strategy for the evangelisation of postmodernists. Paul teaches us that Biblical revelation is the fulcrum of evangelism. The kernel of the message will require at least these twin aspects: God revealed and Christ risen.

Nevertheless, the primacy of Biblical revelation is inseparable from apologetics. Paul did not assume a combative posture nor make a frontal assault on the erroneous positions held by his audience; yet, with admirable delicacy, he challenged and corrected the major positions of both Stoics and Epicureans. Likewise, the sensitivity manifested by Paul in Athens shows how the message can be conveyed to speak relevantly and pointedly to the postmodern society. 


\section{List of references}

BARRETT, C.K. 1998. Acts. Edinburgh: Clarke.

BERGER, P.L. 1992. A far glory: the quest for faith in an age of credulity. New York: Doubleday.

BLEVINS. J.L. 1990. Acts 13-29: the tale of two cities. Review and Expositor, 87(3):439-450, Summer.

BRUCE, F.F. 1990. The Acts of the Apostles. Grand Rapids: Eerdmans.

CARSON, D.A. 1996. The gagging of God. Leicester: Apollos.

CHARLES, J.D. 1995. Engaging the (neo)pagan mind: Paul's encounter with Athenian culture as a model for cultural apologetics (Acts 17-16-34). Trinity Journal, 1(16):47-62, Spring.

DUNN, J.D.G. 1996. The Acts of the Apostles. Valley Forge: Trinity Press International.

FERGUSON, E. 1987. Backgrounds of early Christianity. Grand Rapids: Eerdmans.

FITZMYER, J.A. 1998. The Acts of the Apostles. New York: Doubleday.

GARLAND, R. 1992. Introducing new gods: the politics of Athenian religion. London: Duckworth.

GILL, D.W.J. 1994a. Achaia. (In Gill, D.W.J. \& Gempf, C., eds. The book of Acts in its first century setting: Graeco-Roman setting. Vol. 2. Grand Rapids: Eerdmans. p. 433-453.)

GILL, D.W.J. 1994b. Acts and Roman religion. (In Gill, D.W.J. \& Gempf, C., eds. The book of Acts in its first century setting: Graeco-Roman setting. Vol. 2. Grand Rapids: Eerdmans. p. 79-92.)

GUINNESS, O. 2000. Time for truth: living free in a world of lies, hype and spin. Grand Rapids: Baker Books.

HANCOCK, M. 1994. Dialogue, declaration and dispute: joining the discussion in the marketplace of ideas. Crux, 30(2):9-16, June.

HANSEN, G.W. 1994. Galatia. (In Gill, D.W.J. \& Gempf, C., eds. The book of Acts in its first century setting: Graeco-Roman setting. Vol. 2. Grand Rapids: Eerdmans. p.377-395.)

HANSEN, G.W. 1998. The preaching and defence of Paul. (In Marshall, I.H. \& Peterson, D., eds. Witness to the gospel: the theology of Acts. Grand Rapids: Eerdmans. p. 295-324.)

HEMER, C.J. 1990. The book of Acts in the setting of Hellenistic history. Winona Lake: Eisenbrauns.

JOHNSON, D.E. 1997. The message of Acts in the history of redemption. Phillipsburg: P\&R Publishing.

KEE, H.C. 1997. To every nation under heaven: the Acts of the Apostles. Harrisburg: Trinity Press International.

KISTEMAKER, S.J. 1990. Acts. Grand Rapids: Baker Book House.

KOESTER, H. 1982. History, culture and religion of the Hellenistic age. Vol. 1. New York: De Gruyer.

LOUW, J.P. \& NIDA, E.A., eds. 1988. Greek-English lexicon of the New Testament. Volume 1 \& 2. New York: United Bible Societies.

LYOTARD, J.F. 1984. The postmodern condition: a report on knowledge. Translated by G. Bennington. Minnesota: University of Minnesota Press.

MARSHALL, I.H. 1980. Acts. Grand Rapids: Eerdmans.

MARSHALL, I.H. 1992. Dialogue with non-Christians in the New Testament. Review of Theology,16(1)28-47, January. 
McGRATH, A.E. 1996. A passion for truth. Leicester: InterVarsity.

METZGER, B.M. 1983. The New Testament its content and background. Nashville: Abingdon.

METZGER, B.M. 1994. A textual commentary on the Greek of the New Testament. New York: United Bible Societies.

PROCTOR, J. 1992. The gospel from Athens: Paul's speech before the Areopagus and the evangel for today. Evangel, 10(3):69-72, Autumn.

RODGERS, C.L. 1979. The Dionysian background of Ephesians 5:18. Bibliotheca Sacra, 136(543):249-257, July.

SLOAN, R.B. 1994. Religious background to the New Testament. (In Dockery, D.S. \& Matthews, K.A., eds. Foundations for biblical interpretation. Nashville: Broadman \& Holman. p. 509-522.)

SOARDS, M.L. 1994. The speeches in Acts. Louisville: John Knox.

STOTT, J. 1990. The Spirit the church and the world: the message of Acts. Downers Grove: InterVarsity.

THOMPSON, G.G. 2000. Proclaiming the gospel to postmodernists. Potchefstroom : PU for CHE. (Ph.D. thesis.)

TREBILCO, P. 1994. Asia. (In Gill, D.W.J. \& Gempf, C., eds. The book of Acts in its first century setting: Graeco-Roman setting. Vol. 2. Grand Rapids: Eerdmans. p. 291-362.)

VOS, H.F. 1988. Religion of the Biblical world: Greco-Roman. (In Bromiley, G.W., ed. The international standard Bible encyclopaedia. Vol. 4, Q-Z. Grand Rapids: Eerdmans. p.107-117.)

WALLACE, D.B. 1996. Greek grammar beyond the basis: an exegetical syntax of the New Testament. Grand Rapids: Zondervan.

WILLIAMS, D. 1985. Acts. Peabody: Hendrickson.

WINTER, B.W. 1994. The imperial cult. (In Gill, D.W.J. \& Gempf, C., eds. The book of Acts in its first century setting: Graeco-Roman setting. Vol. 2. Grand Rapids: Eerdmans. p. 93-103.)

WITHERINGTON, B. 1998. The Acts of the Apostles. Grand Rapids: Eerdmans. WOOD, W.J. 1998. Epistemology: becoming intellectually virtuous. Downers Grove: InterVarsity.

Key concepts:

Acts 17:16-34

paradigm

postmodernity

Kernbegrippe:

Handeling 17:16-34

paradigma

postmodernisme 